\title{
Ectoaminopeptidase specificity and regulation in Antarctic marine pelagic microbial communities
}

\author{
James R. Christian*, David M. Karl \\ School of Ocean and Earth Science and Technology, University of Hawaii, Honolulu, Hawaii 96822, USA
}

\begin{abstract}
Ectoaminopeptidase activities of pelagic marine microbial communities were investigated on several research cruises in the western Antarctic Peninsula region from 1992 to 1994, using the fluorigenic substrate analogue L-leucyl- $\beta$-naphthylamine. $K_{\mathrm{m}}$ values at in situ temperature were comparable to those observed by other investigators for a variety of aquatic environments. Competitive inhibition by dipeptides of a variety of amino acids showed that the aminopeptidases present were broadly specific; no strong tendency toward greater affinity for hydrophobic or hydrophilic amino acids was observed. Seawater cultures $(1.0 \mu \mathrm{m}$ filtrate $)$ were inoculated with a variety of monomeric organic compounds and incubated for 24 to $72 \mathrm{~h}$ prior to activity determination; histidine and phenylalanine were found to consistently inhibit aminopeptidase expression. It is hypothesized that auxotrophy for histidine and phenylalanine may be widespread in these assemblages, giving rise to high levels of constitutive, nonspecific aminopeptidase activity which results in significant respiration of the more common amino acids. Whatever the exact mechanism, aminopeptidase activity is strongly affected by the specific compounds present and not simply by the carbon-to-nitrogen ratio.
\end{abstract}

KEY WORDS: Aminopeptidase - Enzyme specificity Enzyme regulation Antarctica

\section{INTRODUCTION}

Hydrolytic ectoenzymes are of great importance to aquatic microorganisms because a significant fraction of the organic matter in natural waters is present in polymeric form (Sharp 1973, Amon \& Benner 1994). Fluorigenic substrate analogues have facilitated the measurement of ectoenzyme activity in natural aquatic habitats (Hoppe 1983, 1993). Among the enzymes most commonly studied, exopeptidases commonly called 'leucine aminopeptidase' appear to be ubiquitous in the sea and play a significant role in microheterotrophic substrate acquisition and biogeochemical cycling (Somville \& Billen 1983, Fontigny et al. 1987 , Billen 1991, Hoppe 1991, Hoppe et al. 1993, Christian 1995, Christian \& Karl 1995a, Martinez et al. 1996). Exopeptidases catalyze the hydrolysis of polymeric amino acids (dipeptides to polypeptides) to monomers. There are many unanswered questions about this class

- Present address: Universities Space Research Association, NASA/GSFC, Code 970.2, Greenbelt, Maryland 20771, USA.

E-mail: jrc@bluefin.gsfc.nasa.gov of enzymes in natural microbial communities, including the kinetic response (natural variability and response to natural, ambient substrate), specificity and diversity (one broadly specific enzyme or several highly specific ones), metallic ion requirements and other cofactors, regulation of expression (constitutive or induced), and localization of the enzyme on the cell surface. Furthermore, this enzyme class plays a significant but as yet poorly quantified role in the carbon and nitrogen nutrition of the microbial community, and more generally in nutrient cycling in the pelagic realm. In this paper we present the results of several experiments that address outstanding questions about the nature of the enzyme or enzymes, and, indirectly, the organisms expressing it.

The Palmer Long-Term Ecological Research (LTER) grid extends for $1000 \mathrm{~km}$ along the western side of the Antarctic Peninsula, from the edge of the continent to just beyond the shelf break (Quetin \& Ross 1992, Smith et al. 1995). Studies of bacterioplankton in this region have shown that their biomass, relative to that of phytoplankton, is less than in other marine and fresh waters (Karl et al. 1991, 1996). The Palmer LTER region 
is an upwelling area, with high inorganic nutrient concentrations $\left(\left[\mathrm{NO}_{3}{ }^{-}\right]>20 \mu \mathrm{M}\right)$, except during the seasonal phytoplankton blooms, and low organic nutrient concentrations (dissolved organic carbon and nitrogen concentrations are generally less than 70 and $4 \mu \mathrm{M}$ respectively). Most of the experiments presented here were conducted when $\left[\mathrm{NO}_{3}{ }^{-}\right]$was $>20 \mu \mathrm{M}$ implying dissolved organic nitrogen concentrations $<4 \mu \mathrm{M}$ (Karl et al. 1996).

Ribosomal rRNA evidence has suggested that Archaea may represent a larger fraction of the microbial community in surface waters in the Antarctic Peninsula region than elsewhere in the ocean (DeLong et al. 1994, Massana et al. in press). Ectoenzyme activities measured in whole water samples cannot be definitely attributed to particular groups of microorganisms. It is probably reasonable to assume that the majority of activity is associated with prokaryotes, but too little is known about Archaea to make informed speculation about their role relative to Bacteria. We therefore refer to enzymatic activity as associated with microbial communities rather than any particular group.

Spatial and temporal variations of in situ leucine aminopeptidase activity in the western Antarctic Peninsula region have been extensively documented (Christian \& Karl 1992, 1993, 1994, 1995a, Christian 1995). In this paper we address several unresolved questions about these enzymes. Firstly, $K_{m}$ determinations show values consistent with those observed in temperate environments ( 67 to $132 \mu \mathrm{M}$ ) at in situ temperature, but somewhat higher at temperatures above $10^{\circ} \mathrm{C}$. Secondly, competitive inhibition of hydrolysis of the model substrate L-leucyl- $\beta$-naphthylamine by dipeptides of a variety of amino acids suggests that hydrolysis of various amino acid linkages is carried out by broadly specific enzymes rather than by a suite of highly specific ones. Finally, ectoaminopeptidase expression appears to be regulated by the availability of specific amino acids even in the presence of abundant $\mathrm{C}$ and $\mathrm{N}$ in highly labile form. Enzyme expression appears to be repressed by several amino acids known to be rare in seawater (histidine and phenylalanine).

\section{MATERIALS AND METHODS}

Study area. Experiments were conducted in the Antarctic Peninsula region of the Southern Ocean, in the Palmer LTER study area (Quetin \& Ross 1992, Smith et al. 1995). RV 'Polar Duke' (PD) and RVIB 'Nathaniel B. Palmer' (NBP) cruise designations were: PD92-09 (November 1992), NBP93-02 (March-May 1993), PD94-01 (January-February 1994) and PD94-12 (December 1994).
Ectoenzyme assays. The method of using fluorigenic substrate analogues as tracers for ectoenzymatic activity in natural waters was introduced by Hoppe (1983) and Somville \& Billen (1983); a useful summary is given by Hoppe (1993). The substrate analogue used was L-leucyl- $\beta$-naphthylamine (LLBN) (Somville \& Billen 1983, Christian \& Karl 1995a). The enzyme(s) hydrolyzing LLBN is referred to as leucine aminopeptidase (EC 3.4.1.1) and abbreviated as LAPase. $\beta$-Naphthylamine external fluorescence standards were prepared as described by Christian \& Karl (1995b). Fluorescence was determined in a Perkin-Elmer LS-5B spectrofluorometer with quartz cuvettes. Excitation and emission wavelengths were 337 and $411 \mathrm{~nm}$ respectively, with $10 \mathrm{~nm}$ bandwidths.

LLBN was added to $6 \mathrm{ml}$ of seawater and incubated for 12 to $24 \mathrm{~h}$. All incubations were conducted in the dark. In experiments where seawater cultures were incubated with supplemental $N$ compounds prior to activity determination (regulation experiments), LLBN was added at saturating concentration (1 mM). Samples not analyzed immediately following the incubation were poisoned with $0.1 \mathrm{ml}$ of a saturated solution of mercuric chloride (final concentration $-4 \mathrm{mM}$ ) to stop the reaction, and stored frozen (Christian \& Karl 1995b). Mercuric chloride precipitates excess LLBN which was removed by filtration $(0.2 \mu \mathrm{m}$, Gelman Acrodisc ${ }^{(\otimes)}$ ) or centrifugation prior to fluorescence determination.

Fluorescence was corrected for nonenzymatic hydrolysis and background fluorescence of the substrate analogue by subtracting the fluorescence of control samples with mercuric chloride added at time zero (Christian \& Karl 1995b). Activity in nmol $\mathrm{l}^{-1} \mathrm{~h}^{-1}$ was calculated as $\left(F-F_{0}\right) \cdot A / t$, where $F_{0}$ is the control fluorescence, $A$ is the concentration in nM given by 1 fluorescence (arbitrary) unit and $t$ is the incubation time in hours.

Specificity. Specificity experiments were conducted by incubating freshly collected seawater with subsaturating concentrations of LLBN and dipeptides of various amino acids. All of the dipeptides used were homodipeptides except Ser-Leu (serine N-terminal). Experiments were conducted in both kinetic (with several concentrations of both LLBN and the competing dipeptide) and nonkinetic fashion (with a single concentration of each). In the nonkinetic experiments the concentrations of the dipeptides were approximately 3 times the LLBN concentration. In the kinetic experiments the concentrations were chosen to span the region of saturation response, where competitive effects are most strongly displayed.

Sample preparation for seawater cultures. Seawater cultures for ectoenzyme regulation experiments were prepared by filtering freshly collected seawater to 
incubate picoplankton in the absence of grazers prior to LAPase activity determination. Seawater was filtered through $1.0 \mu \mathrm{m}$ polycarbonate membrane filters (Nuclepore) using an enclosed polycarbonate collection vessel (Nalgene). This apparatus was rinsed thoroughly with $10 \% \mathrm{HCl}$, then rinsed 2 or 3 times with distilled water and 2 or 3 times with sample water Organic substrates were added at concentrations much lower than the concentration of LLBN added in the LAPase assay to exclude potential effects of product inhibition.

Data analysis. The Henri-Michaelis-Menten equation, and the expanded Henri-Michaelis-Menten equation

$$
V=\frac{V_{\max } S}{K_{\mathrm{m}}\left(1+\frac{I}{K_{I}}\right)+S}
$$

where $I$ is the concentration of a second, competing substrate and $K_{I}$ is the equilibrium constant for its binding to the enzyme, were fit to the data using a nonlinear least-squares (Gauss-Newton) algorithm based on Tarantola (1987) and Johnson \& Faunt (1992). This algorithm will converge upon the values of the model parameters that minimize the sums of squares of the residuals, which is equivalent to the maximum likelihood value if the standard assumptions of leastsquares are met (errors Gaussian and uncorrelated. errors in independent variable negligible, sufficient data to give representative sample of errors). As with all nonlinear curve-fitting routines, initial parameter estimates must be reasonable for convergence to occur. In most cases values derived from linear transformations (e.g. Lineweaver-Burk) using model I linear regression were adequate.

\section{RESULTS}

\section{Temperature and concentration response}

The apparent $K_{\mathrm{m}}$ for LAPase was in the range of 48 to $218 \mu \mathrm{M}$ over all temperatures assayed $\left(-1.7\right.$ to $\left.+20^{\circ} \mathrm{C}\right)$ and 67 to $132 \mu \mathrm{M}$ at in situ temperature $\left(-1.7\right.$ to $\left.+2^{\circ} \mathrm{C}\right)$ (Fig. 1). Values at in situ temperature fall within the range observed by other investigators for LAPase in seawater (Hoppe 1983, Somville \& Billen 1983, Fontigny et al. 1987). Values obtained at higher temperatures (i.e. temperatures typical of the in situ temperatures in the temperate waters where most other investigators have determined $K_{\mathrm{m}}$ for LAPase) are somewhat higher. Maximum values were not observed in individual experiments, but a composite of several experiments suggests a maximum at $\sim 15^{\circ} \mathrm{C}$ (Fig. 1). A minimum at 4 to $6^{\circ} \mathrm{C}$ was observed several times. This cannot be shown to be statistically significant with these data, but

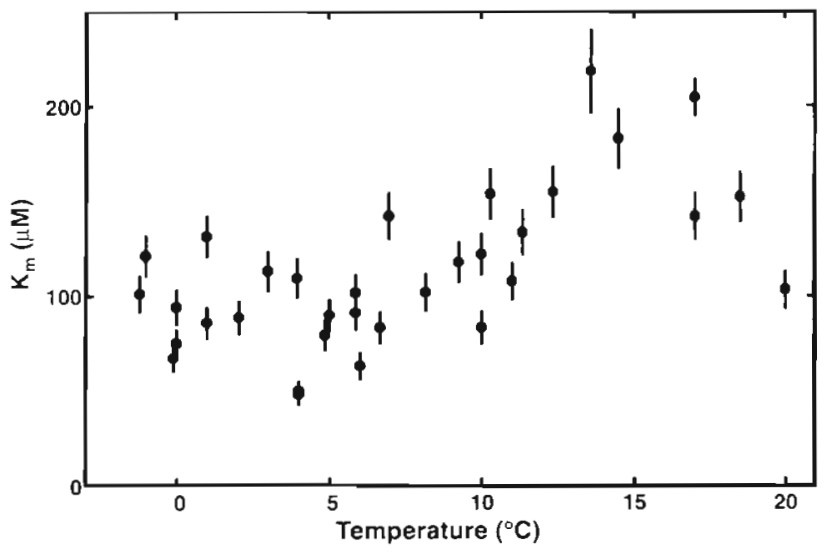

Fig. 1. Relationship of $K_{\mathrm{m}}$ for hydrolysis of L-leucyl- $\beta$-naphthylamine in Antarctic seawater to incubation temperature. Error bars are 1 standard deviation

it appeared consistently enough to suggest that it was not purely stochastic variability. Other results regarding temperature responses of LAPase in Antarctic microbiota are given by Christian \& Karl (1995a).

\section{Specificity}

The specificity of the enzyme or enzymes hydrolyzing LLBN was investigated in austral autumn 1993 (NBP-9302) by competitive inhibition experiments with selected dipeptides. All of the dipeptides used showed some evidence of inhibition, including Dleucine (Fig. 2). Differences among the various amino acids added were small, and no clear order of relative affinities was observed (Fig. 2).

Double-reciprocal (Lineweaver-Burk) plots followed, in most cases, the pattern expected for competitive inhibition (Fig. 3A). The values of $K_{\mathrm{m}}$ and $V_{\max }$ calculated by nonlinear least-squares are suggestive of competitive inhibition, with $K_{\mathrm{m}}$ increasing in the presence of a competing dipeptide (data not shown). However, the a posteriori variances of the model parameter estimates were generally large, and in some cases $V_{\max }$ also increased. The values of $V_{\max }, K_{\mathrm{m}}$ and $K_{l}$ estimated from the expanded Henri-Michaelis-Menten equation (Eq. 1) predicted the measured activities reasonably well in most cases (Fig. 3B).

\section{Regulation by organic and inorganic nitrogen sources}

The effects of a variety of nitrogen compounds on LAPase expression were examined by incubating seawater supplemented with these compounds for 24 to 

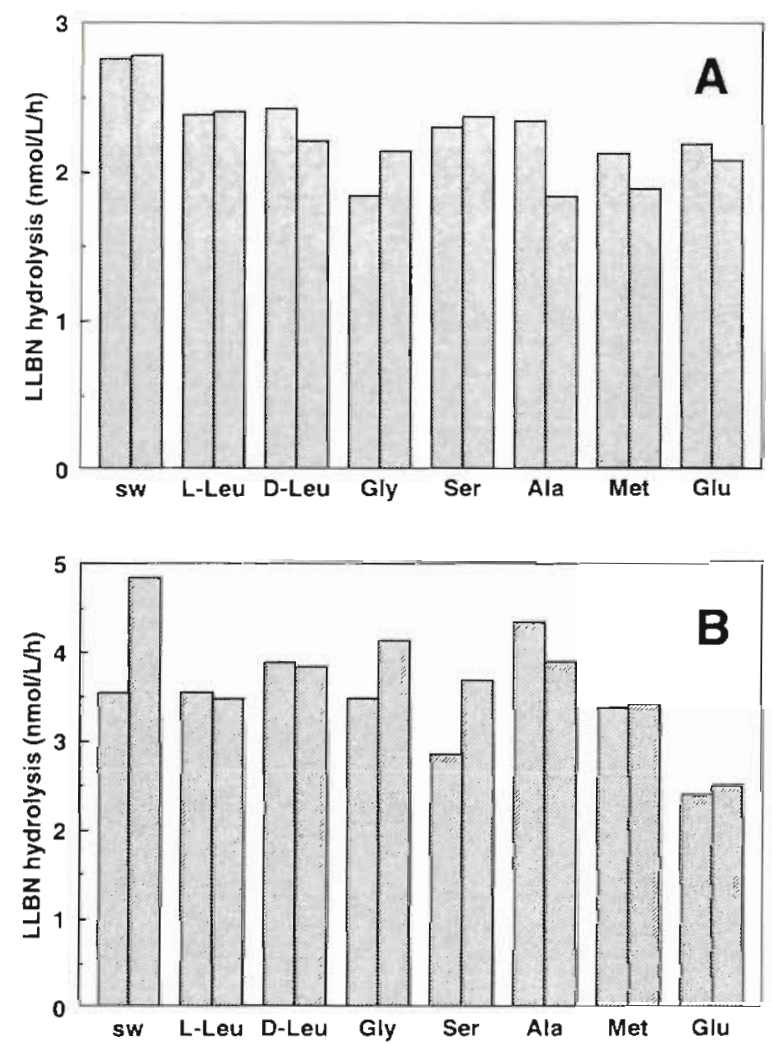

Fig. 2. Rate of LLBN (L-leucyl- $\beta$-naphthylamine) hydrolysis in the presence of potentially competing dipeptides of various amino acids. (A) Dipeptide concentrations are $80 \mu \mathrm{M}$ and LLBN concentration is $35 \mu \mathrm{M}$. (B) Dipeptide concentrations are $148 \mu \mathrm{M}$ and LLBN concentration is $49 \mu \mathrm{M}$. All amino acids are L-forms except where specified; there are 2 replicates for each treatment

$74 \mathrm{~h}$ prior to ectoenzyme activity determination. Preliminary experiments in November 1992 (PD92-09) showed large increases in LAPase activity over $50 \mathrm{~h}$ in filtered $(1.0 \mu \mathrm{m})$ seawater. Increases similar to those in unsupplemented controls occurred in the presence of supplemental nitrogen as $\mathrm{NH}_{4}{ }^{+}(200 \mu \mathrm{M})$ or amino acids (glycine and proline added at $100 \mu \mathrm{M}$ each) (Fig. 4). Therefore, nitrogen availability alone is a poor predictor of LAPase expression.

On subsequent cruises in January-February 1994 (PD94-01) and December 1994 (PD94-12), the requlatory effects on LAPase of a wider variety of nitrogen compounds, mostly amino acids, were tested. Histidine, and to a lesser extent phenylalanine, significantly repressed LAPase expression, relative to glycine or glucose added at identical molar concentrations of $\mathrm{C}$ and $\mathrm{N}$ (additional $\mathrm{N}$ added as $\mathrm{NH}_{4} \mathrm{Cl}$ where required) (Fig. 5). Other amino acids including tyrosine and leucine had no effect even at concentrations that should provide a more than adequate source of organic $\mathrm{N}$ in a highly labile form (data not shown). The effect of incu-
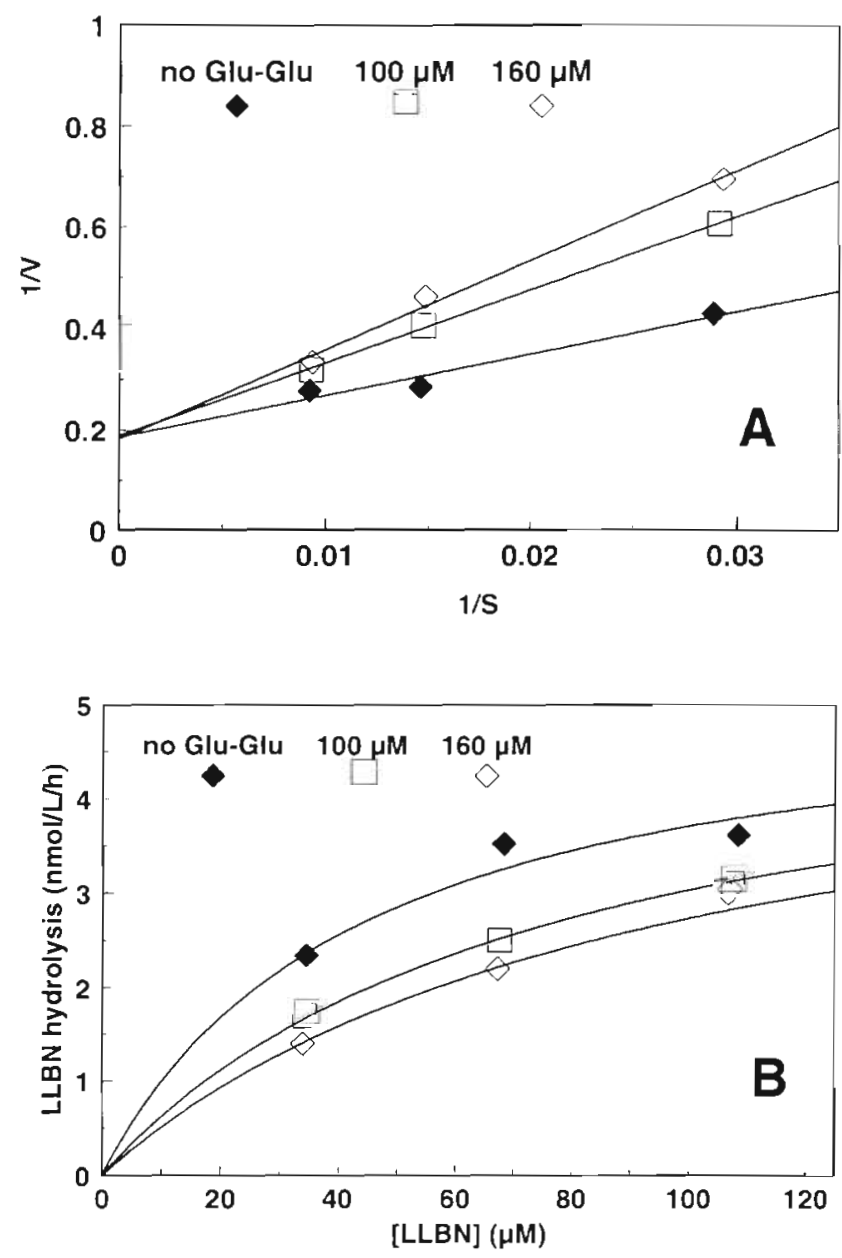

Fig. 3. (A) Example double reciprocal (Lineweaver-Burk) plot showing competitive inhibition of L-leucyl- $\beta$-naphthylamine (L.LBN) hydrolysis by L-Glu-L-Glu. Substrate concentrations (S) are in $\mu \mathrm{M}$ and activities (V) in $\mathrm{nmol} \mathrm{l}^{-1} \mathrm{~h}^{-1}$ Lines are model I linear regression. (B) Rate of LLBN hydrolysis in the presence of L-Glu-L-Glu (symbols), shown relative to values predicted by expanded Henri-Michaelis-Menten equation (Eq. 1) with model parameters estimated by nonlinear least-squares (curves)

bation with added histidine was highly consistent and reproducible (Table 1). It was observed in unfiltered seawater (i.e. in the presence of grazing microzooplankton), but the percent difference, relative to the controls, was less than in $1.0 \mu \mathrm{m}$ filtered seawater (Table 1)

\section{DISCUSSION}

Aminopeptidase activity has been shown to be widespread if not ubiquitous in the marine environment and among marine Bacteria (Christian 1995, Christian \& Karl 1995a, Martinez et al. 1996), but little is known 

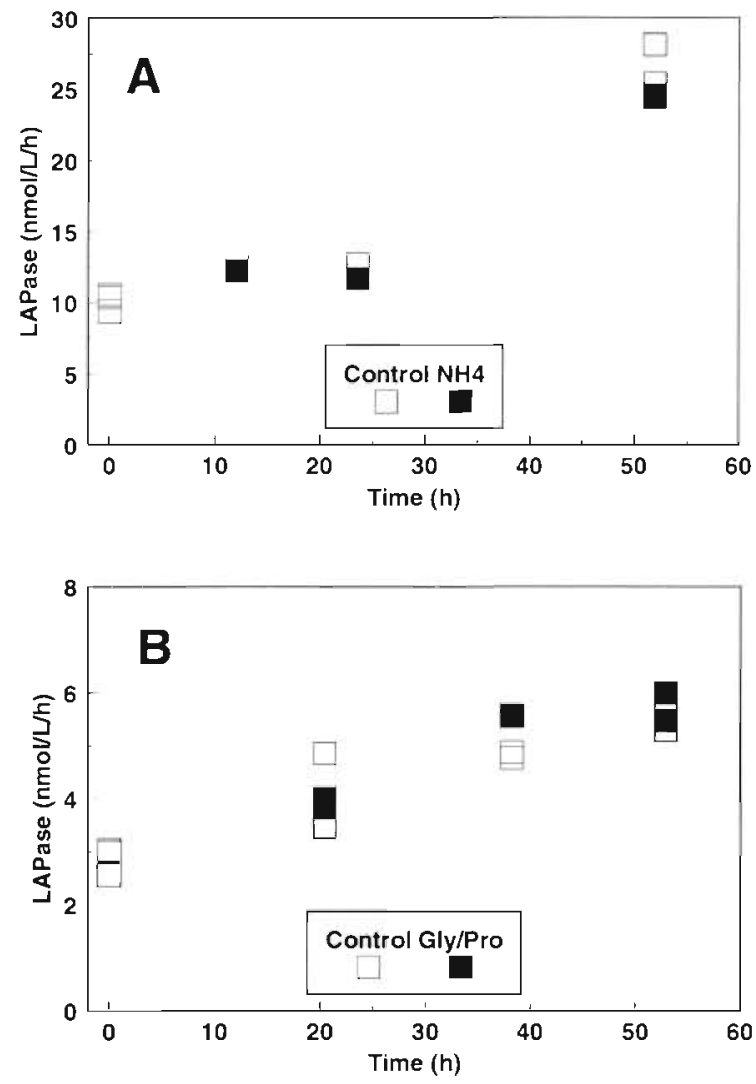

Fig. 4. Time course of LAPase (leucine aminopeptidase) activity $\left(\mathrm{nmol} \mathrm{l}^{-1} \mathrm{~h}^{-1}\right)$ in $1.0 \mu \mathrm{m}$ filtered surface seawater with and without added (A) $\mathrm{NH}_{4} \mathrm{Cl}(200 \mu \mathrm{M})$ and (B) glycine + proline (each $100 \mu \mathrm{M}$ ). All replicate subsamples shown. The experiment was conducted in November 1992 (PD92-09); concentration of LLBN was $1 \mathrm{mM}$

about the enzyme or enzymes involved. We have referred to the enzyme(s) hydrolyzing LLBN as 'leucine aminopeptidase' (LAPase), implying an enzyme that most rapidly cleaves leucine residues but with relatively broad specificity (Delange \& Smith 1971). Broadly specific enzymes should be evolutionarily advantageous in this context (ectoenzymes whose func-

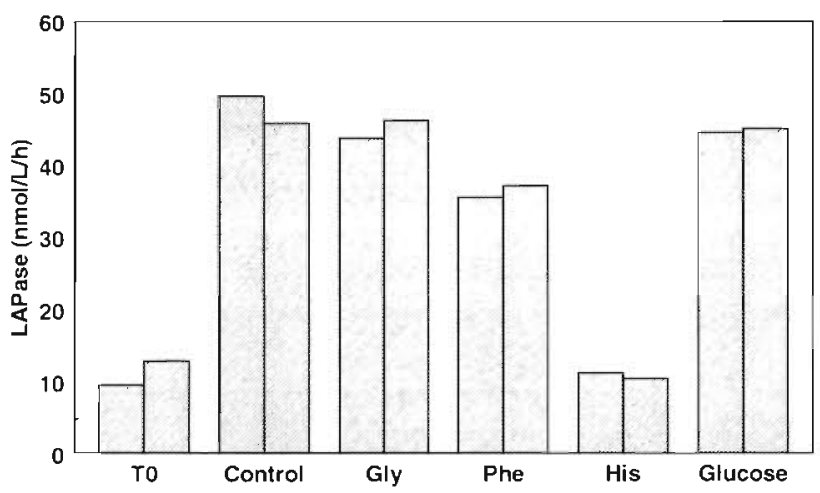

Fig. 5. LAPase activity in $1.0 \mu \mathrm{m}$ filtered surface seawater following $48 \mathrm{~h}$ incubation with monomeric organic compounds. All supplemental compounds added at $\mathrm{C}$ and $\mathrm{N}$ molar equivalent of $10 \mu \mathrm{M}$ histidine, with additional nitrogen added as $\mathrm{NH}_{4} \mathrm{Cl}$. The experiment was conducted in December 1994 (PD94-12); concentration of LLBN was $1 \mathrm{mM}$. Adjacent bars are duplicate subsamples

tion is to get nutrients from the medium). There is some suggestion in the competitive inhibition experiments described that LAPases in these microbial communities may have greatest affinity for acidic residues (Fig. 2B), as for example aminopeptidases A (Delange \& Smith 1971). However, this result is not statistically significant. In addition, competitive inhibition of LLBN hydrolysis by these dipeptides demonstrates only that they bind to the active site; it is only assumed that they are hydrolyzed.

A variety of $\mathrm{N}$-terminal aminopeptidases have been isolated from Bacteria (e.g. Prescott \& Wilkes 1966, Vogt 1970, Prescott et al. 1971). Escherichia coli has at least 5, of which 3 have broad specificity (Miller 1987). The basic structure of these enzymes is likely to be evolutionarily ancient and common to diverse types of organisms (cf. Kim \& Lipscomb 1994). That such an enzyme is broadly distributed among native aquatic prokaryotes is suggested by the similar $K_{\mathrm{m}}$ values observed in widely separated regions of the ocean (Somville \& Billen 1983, Fontigny et al. 1987, Christian

Table 1. Percent inhibition of LAPase activity by added histidine (His), relative to unamended controls. Samples filtered (1.0 $\mu \mathrm{m}$ ) unless otherwise noted

\begin{tabular}{|lcccl|}
\hline Date & Preincubation (h) & [His] $(\mu \mathrm{M})$ & LAPase (\% of control) & Comments \\
\hline Jan 1994 & 24 & 80 & 52 & \\
Jan 1994 & 72 & 80 & 16 & \\
Jan 1994 & 48 & 80 & 49 & (His + heat-sterilized brown ice), vs unamended control \\
Jan 1994 & 48 & 80 & 58 & (His + heat-sterilized brown ice), vs ice only \\
Dec 1994 & 48 & 10 & 51 & Unfiltered seawater \\
Dec 1994 & 48 & 10 & 65 & Bloom conditions, high chlorophyll \\
Dec 1994 & 48 & 10 & 23 & \\
\hline
\end{tabular}


1995) and by the presence of a very similar enzyme in cultures of the cyanobacterium Synechococcus sp. (Martinez \& Azam 1993). Martinez et al. (1996) examined 44 bacterial strains isolated from seawater, all of which possessed aminopeptidase activity.

The metal or other cofactors of LAPase in seawater remain largely unknown, but there is some consistency about the metal requirements of prokaryotic aminopeptidases. Fontigny et al. (1987) suggested that metalloproteases dominated LAPase in seawater because activity was strongly inhibited by EDTA, but did not identify the metals involved. Most LAPases are activated principally by $\mathrm{Zn}^{2+}$ but also by $\mathrm{Mn}^{2+}$ and $\mathrm{Co}^{2+}$ (Kim \& Lipscomb 1994). An endopeptidase activated by these same 3 elements was reported by Krupyanko et al. (1989). Aminopeptidases A (acidic residue-preferring) are generally $\mathrm{Zn}$ enzymes (Wang \& Cooper 1993). Rul et al. (1995), however, reported an aminopeptidase A from Streptococcus thermophilus that is activated most strongly by $\mathrm{Mg}^{2+}$, and also activated by $\mathrm{Co}^{2+}$ and $\mathrm{Zn}^{2+}$, but not by $\mathrm{Mn}^{2+}$.

Trace element cofactors could play a substantial role in carbon and nitrogen biogeochemistry through ectoenzyme evolution and activity regulation because the sources of the elements discussed above differ substantially among different regions of the ocean. Of the bioactive trace elements, $\mathrm{Zn}$ and Co have among the lowest concentrations in open ocean surface water (Donat \& Bruland 1995), so Mn could play an important role in activating this enzyme in some regions of the ocean. In Antarctic oceanic waters input of aeoliansource metals including $\mathrm{Mn}$ and $\mathrm{Co}$ is small, and concentrations of nutrient-type elements like $\mathrm{Zn}$ relatively high (Martin et al. 1990. Duce \& Tindale 1991, Duce et al. 1991). Neritic Antarctic waters are somewhat enriched in both types of elements (Martin et al. 1990), but the solubility of $\mathrm{Mn}$ and Co is low in oxygenated waters.

The results of the substrate-addition experiments indicate that ectoenzyme activity is strongly affected by the availability of specific compounds known to be rare in seawater. The decline in LAPase activity following incubation with His or Phe may result from repression of enzyme activity, succession of species or strains within the incubation containers, or a combination of the two. In either case, it is clearly the availability of specific compounds and not of bioavailable nitrogen in general that determines the level of activity expressed by the community as a whole. Species lacking LAPases might come to dominate within the His-amended containers by superior ability to compete for e.g. orthophosphate, but did not do so in containers amended with monomeric amino acids other than His or Phe. In addition, as noted above, Martinez et al. (1996) examined 44 seawater isolates for LAPase activity and did not find any lacking it. Another possible interpretation is that His, at these concentrations, is toxic to many of the microorganisms present, and that the decline in LAPase simply reflects decline in the number of active cells. This (admittedly improbable) explanation cannot be entirely overlooked, as we did not determine cell numbers, which could not in any case exclude this posibility, as dead or dying cells may be included in the total count (Zweifel \& Hagström 1995). Another possibility is that many of the microorganisms present are auxotrophic for other amino acids as well, but that LAPase is not repressed by additions of these because of high natural background concentrations. However, concentrations of monomeric amino acids are generally low in seawater (e.g. Tupas et al. 1994).

Our results contrast strongly with those of Chróst (1991), who found that glucose, acetate and an amino acid mixture (which included neither histidine nor phenylalanine) repressed LAPase activity in a temperate eutrophic lake. By contrast, our results are consistent with those of Rivkin et al. (1991), who found little or no increase in bacterial growth as determined by thymidine uptake with addition of monomeric compounds such as glucose, glutamic acid and glycine, but not necessarily with their interpretation. They hypothesized that Antarctic bacterioplankton are 'substrate sufficient' and that growth is limited by some other factor, such as temperature. An alternative explanation suggested by our results is that the communities used in their experiments were in fact limited by substrate availability, but the compounds they added were not the ones required to increase growth rates.

Because of the consistency of repression of LAPase by histidine, we advance the hypothesis that a large fraction of the Bacteria and/or Archaea in our study area are auxotrophic for this amino acid. Auxotrophy for amino acids is widespread among Bacteria (Guirard $\&$ Snell 1962). Of 15 strains isolated from seawater by Ostroff \& Henry (1939), only 5 could grow with ammonium as the sole nitrogen source. Two hyperthermophilic heterotrophic Archaea (one from each of the major kingdoms within the Archaea) isolated from deep-sea hydrothermal sulfide deposits were auxotrophic for 11 different amino acids (Hoaki et al. 1993).

There are several observations for which the auxotrophic hypothesis suggests explanations. Amino acid respiration appears to be a major pathway for $\mathrm{C}$ and $\mathrm{N}$ cycling in pelagic marine ecosystems of the Western Antarctic Peninsula (Tupas et al. 1994). If histidine requirements cause LAPases to be expressed at higher levels than are required to satisfy basic carbon and nitrogen requirements, the flux of amino acids to the cell should exceed that required for biosynthesis (which is limited by availability of amino acids not synthesized), so that a substantial fraction is respired. 
Widespread respiration of amino acids would help to explain why the ratio of aminopeptidase activity to that of glucosidases is higher in Antarctica than elsewhere (Christian \& Karl 1995a).

The results presented here can be summarized as follows. Firstly, values of $K_{\mathrm{m}}$ for LAPase were generally consistent with those from other aquatic environments. Secondly, enzymes hydrolyzing LLBN appear to be broadly specific. Hydrolysis of the fluorigenic substrate analogue was not more strongly inhibited by L-Leu-LLeu than by dipeptides of other amino acids, and Lineweaver-Burk plots characteristic of competitive inhibition were obtained in some cases. Finally, expression of this enzyme(s) appears to be regulated by availability of amino acids known to be rare in seawater (histidine and phenylalanine). It is highly probable that growth and metabolism of heterotrophic prokaryotes is regulated by the mixture of compounds available and not simply by $\mathrm{C}$ or $\mathrm{N}$ availability. The hypothesis of auxotrophy for these amino acids is advanced to explain the latter observation. These observations suggest important future areas for research on biosynthesis and growth regulation in aquatic prokaryotes.

Acknowledgements. Financial support for this research wis provided by the National Science Foundation through grant OPP-9118439 to D.M.K. J.R.C. was supported by a Global Change Fellowship from the National Aeronautics and Space Administration, and in the final writing at Dalhousie University by an Isaak Walton Killam postdoctoral fellowship and by the NSERC CJGOFS program. This work was part of the Ph.D. dissertation of J.R.C. at the University of Hawaii (D.M.K., Chair), and we thank the Ph.D. committee members, Robert Bidigare, James Cowen, Michael Landry and Marguerite Volini, for their comments. John Berges, Alison Murray, Philippe Tortell, and 3 anonymous reviewers made useful comments on earlier drafts of this manuscript. We thank the captains and crews of the RV 'Nathaniel B. Palmer' and the RV 'Polar Duke', and the staff of Palmer Station and Antarctic Support Associates for logistical support. John Dore, Terrence Houlihan and Georgia Tien helped with sample collection on NBP93-02. SOEST publication number 4539.

\section{LITERATURE CITED}

Amon RMW, Benner R (1994) Rapid cycling of high-molecular-weight dissolved organic matter in the ocean. Nature 369:549-552

Billen G (1991) Protein degradation in aquatic environments In: Chróst RJ (ed) Microbial enzymes in aquatic environments. Springer-Verlag, Berlin, p 123-143

Christian JR (1995) Biochemical mechanisms of bacterial utilization of dissolved and particulate organic matter in the upper ocean. PhD thesis, University of Hawaii, Honolulu

Christian JR, Karl DM (1992) Exocellular enzyme activities in Gerlache Strait, Antarctica. Antarct J US 27:170-171

Christian JR, Karl DM (1993) Bacterial exoprotease activities in the Antarctica Peninsula region during austral autumn 1993. Antarct J US 28:221-222

Christian JR, Karl DM (1994) Relative activities of several bacterial exoenzymes in the Western Antarctic Peninsula during austral summer evidence of sea ice influence on pelagic bacterial communities. Antarct J US 29: $212-214$

Christian JR, Karl DM (1995a) Bacterial ectoenzyme activities in marine waters: activity ratios and temperature responses in three oceanographic provinces. Limnol Oceanogr 40: $1042-1049$

Christran JR, Karl DM (1995b) Measuring bacterial ectoenzyme activities in marine waters using mercuric chloride as a preservative and a control. Mar Ecol Prog Ser 123: $217-224$

Chróst RJ (1991) Environmental control of the synthesis and activity of aquatic microbial ectoenzymes. In: Chrost RJ (ed) Microbial enzymes in aquatic environments. SpringerVerlag, New York, p 29-59

Delange RJ, Smith EL (1971) Leucine aminopeptidase and other N-terminal exopeptidases. In: Boyer PD (ed) The enzymes, Vol III, Hydrolysis: peptide bonds. Academic, New York, p 81-118

DeLong EF, Wu KY, Prézelin BB, Jovine RVM (1994) High abundance of Archaea in Antarctic marine picoplankton. Nature 371:695-697

Donat JR, Bruland KW (1995) Trace elements in the oceans. In: Salbu B, Steinnes E (eds) Trace elements in natural waters. CRC Press, Boca Raton, p 247-281

Duce RA et al. (1991) The atmospheric input of trace species to the world ocean. Global Biogeochem Cycles 5:193-259

Duce RA, Tindale NW (1991) Atmospheric transport of iron and its deposition in the ocean. Limnol Oceanogr 36 . $1715-1726$

Fontigny A, Billen G, Vives-Rego J (1987) Some kinetic characteristics of exoproteolytic activity in coastal seawater. Estuar Coast Shelf Sci 25:127-133

Guirard BM, Snell EE (1962) Nutritional requirements of microorganisms. In: Gunsalus IC, Stanier RY (eds) The bacteria, Vol 4, The physiology of growth. Academic, New York, p 33-93

Hoaki T, Wirsen CO, Hanzawa S, Maruyama T, Jannasch HW (1993) Amino acid requirements of two hyperthermophilic Archaeal isolates from deep-sea vents, Desulfurococcus strain SY and Pyrococcus strain GB-D. Appl Environ Microbiol 59:610-613

Hoppe HG (1983) Significance of exoenzymatic activities in the ecology of brackish water: measurements by means of methylumbelliferyl substrates. Mar Ecol Prog Ser 11: 299-308

Hoppe HG (1991) Microbial extracellular enzyme activity: a new key parameter in aquatic ecology. In: Chróst RJ (ed) Microbial enzymes in aquatic environments. Springer-Verlag, New York, p 60-83

Hoppe HG (1993) Use of fluorogenic model substrates for extracellular enzyme activity (EEA) measurement of bacteria. In: Kemp PF, Sherr BF, Sherr EB, Cole JJ (eds) Handbook of methods in aquatic microbial ecology. Lewis, Boca Raton, p 423-431

Hoppe HG, Ducklow H, Karrasch B (1993) Evidence for dependency of bacterial growth on enzymatic hydrolysis of particulate organic matter in the mesopelagic ocean. Mar Ecol Prog Ser 93:277-283

Johnson ML, Faunt LM (1992) Parameter estimation by leastsquares methods. Methods Enzymol 210:1-37

Karl DM, Christian JR, Dore JE, Letelier RM (1996) Microbiological oceanography in the region west of the Antarctic Peninsula: microbial dynamics, nitrogen cycle and carbon flux. In: Ross RR, Hofmann EE, Quetin LB (eds) Foundations for ecological research west of the Antarctic Peninsula. AGU, Washington, p 303-332 
Karl DM. Holm-Hansen O. Taylor GT, Tien G. Bird DF (1991) Microbial biomass and productivity in the western Bransfield Strait, Antarctica during the 1986-87 austral summer Deep-Sea Res 38:1029-1055

Kim H, Lipscomb WN (1994) Structure and mechanism of bovine lens leucine aminopeptidase. Adv Enzymol Relat Area Mol Biol 68:153-213

Krupyanko VI, Kudryavtseva AI, Valiakhmetov AY, Severin Al, Abramochkin GV, Zyakun AM, Lysogorskaya YN, Philippova IY, Kulaev IS, Stepanov VM (1989) Substrate specificity of neutral metalloproteinase of the enzyme preparation of lysoamidase isolated from the culture fluid of Pseudomonadaceae. Biochemistry (Moscow) 54: 1140-1149 (in Russian with English summary)

Martin JH, Gordon RM, Fitzwater SE (1990) Iron in Antarctic waters. Nature 345:156-158

Martinez J, Azam F (1993) Aminopeptidase activity in marine chroococcoid cyanobacteria. Appl Environ Microbiol 59: 3701-3707

Martinez J, Smith DC, Steward GF, Azam F (1996) Variability in ectohydrolytic enzyme activities of pelagic marine bacteria and its significance for substrate processing in the sea. Aquat Microb Ecol 10:223-230

Massana R, Taylor LT, Murray AE, Wu KY, Jeffrey WH, DeLong EF (in press) Distribution of marine planktonic Archaea in the Gerlache Strait (Antarctic Peninsula) during early spring. Limnol Oceanogr

Miller CG (1987) Protein degradation and proteolytic modification. In: Neidhardt FC (ed) Escherichia coli and Salmonella typhimurum: cellular and molecular biology. ASM, Washington, p 680-691

Ostroff R, Henry BS (1939) The utilization of various nitrogen compounds by marine bacteria. J Cell Comp Physiol 13: $353-371$

Prescott JM, Wilkes SH (1966) Aeromonas aminopeptidase: purification and some general properties. Arch Biochem Biophys 117:328-336

Editorial responsibility: Farooq Azam,

La Jolla, California, USA
Prescott JM, Wilkes SH, Wagner FW, Wilson KJ (1971) Aeromonas aminopeptudase: improved isolation and some physical properties. J Biol Chem 246:1756-1764

Quetin LB. Ross RM (1992) A long-term ecological research strategy for polar environmental research. Mar Pollut Bull 25:233-238

Rivkin RB, Anderson MR, Gustafson DE Jr (1991) Dynamics of bacterioplankton growth in McMurdo Sound, Antarctica: evidence for substrate sufficient growth. Antarct J US 26 : $145-146$

Rul F, Gripon JC, Monnet V (1995) St-PepA, a Streptococcus thermophilus aminopeptidase with high specificity for acidic residues. Microbiology 141:2281-2287

Sharp JH (1973) Size classes of organic carbon in seawater Limnol Oceanogr 18:441

Smith RC, Baker KS, Fraser WR, Hofmann EE, Karl DM, Klinck JM, Quetin LB, Prezelin BB, Ross RM, Trivelpiece WZ, Vernet $M$ (1995) The Palmer LTER: a long-term ecological research program at Palmer Station, Antarctica. Oceanography 8:77-86

Somville $M$, Billen G (1983) A method for determining exoproteolytic activity in natural waters. Limnol Oceanogr 28 : $190-193$

Tarantola A (1987) Inverse problem theory: methods for data fitting and model parameter estimation. Elsevier, New York

Tupas LM, Koike I, KarI DM, Holm-Hansen O (1994) Nitrogen metabolism by heterotrophic bacterial assemblages in Antarctic coastal waters. Polar Biol 14:195-204

Vogt VM (1970) Purification and properties of an aminopeptidase from Escherichia coli. J Biol Chem 245:4760-4769

Wang J, Cooper MD (1993) Histidine residue in the zinc binding motif of aminopeptidase $A$ is critical for enzymatic activity. Proc Natl Acad Sci USA 90:1222-1226

Zweifel UL, Hagström $\AA$ (1995) Total counts of marine bacteria include a large fraction of non-nucleoid-containing bacteria (ghosts). Appl Environ Microbiol 61:2180-2185

Submitted: May 16, 1997; Accepted: February 9, 1998

Proofs received from author(s): June 22, 1998 